ANTIMICROBIAL RESISTANCE \& INFECTION CONTROL

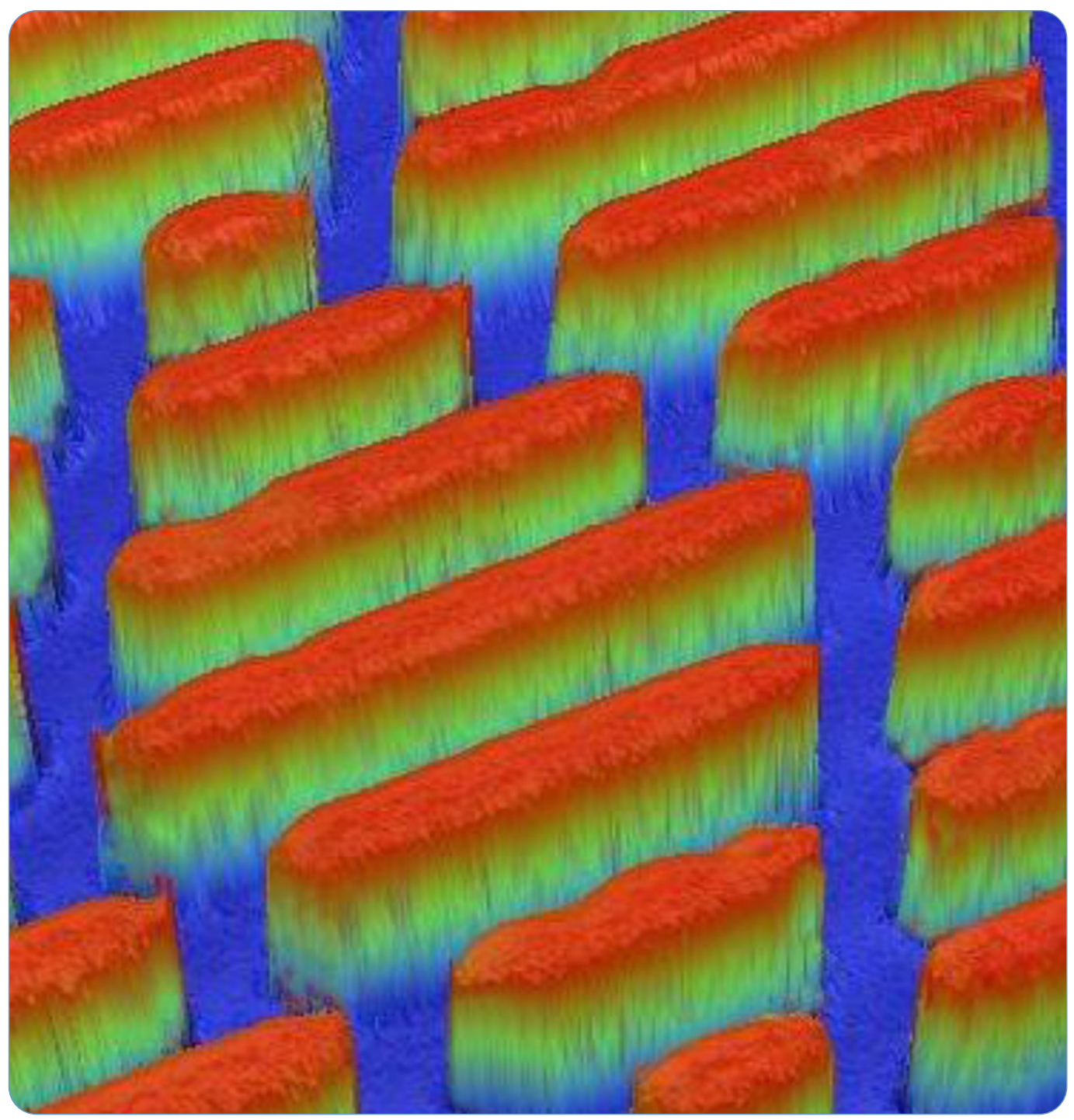

\title{
Surface micropattern limits bacterial contamination
}

Mann et al. 


\title{
Surface micropattern limits bacterial contamination
}

\author{
Ethan E Mann', Dipankar Manna', Michael R Mettetal ${ }^{1}$, Rhea M May ${ }^{1}$, Elisa M Dannemiller ${ }^{1}$, Kenneth K Chung ${ }^{1}$, \\ Anthony B Brennan ${ }^{2}$ and Shravanthi T Reddy ${ }^{1^{*}}$
}

\begin{abstract}
Background: Bacterial surface contamination contributes to transmission of nosocomial infections. Chemical cleansers used to control surface contamination are often toxic and incorrectly implemented. Additional non-toxic strategies should be combined with regular cleanings to mitigate risks of human error and further decrease rates of nosocomial infections. The Sharklet micropattern (MP), inspired by shark skin, is an effective tool for reducing bacterial load on surfaces without toxic additives. The studies presented here were carried out to investigate the MP surfaces capability to reduce colonization of methicillin-sensitive Staphylococcus aureus (MSSA) and methicillin-resistant S. aureus (MRSA) compared to smooth control surfaces.
\end{abstract}

Methods: The MP and smooth surfaces produced in acrylic film were compared for remaining bacterial contamination and colonization following inoculation. Direct sampling of surfaces was carried out after inoculation by immersion, spray, and/or touch methods. Ultimately, a combination assay was developed to assess bacterial contamination after touch transfer inoculation combined with drying (persistence) to mimic common environmental contamination scenarios in the clinic or hospital environment. The combination transfer and persistence assay was then used to test antimicrobial copper beside the MP for the ability to reduce MSSA and MRSA challenge.

Results: The MP reduced bacterial contamination with log reductions ranging from 87-99\% $(L R=0.90-2.18 ; p<0.05)$ compared to smooth control surfaces. The MP was more effective than the $99.9 \%$ pure copper alloy C11000 at reducing surface contamination of S. aureus (MSSA and MRSA) through transfer and persistence of bacteria. The MP reduced MSSA by as much as $97 \%(\mathrm{LR}=1.54 ; p<0.01)$ and MRSA by as much as $94 \%(\mathrm{LR}=1.26 ; p<0.005)$ compared to smooth controls. Antimicrobial copper had no significant effect on MSSA contamination, but reduced MRSA contamination by $80 \%(\mathrm{LR}=0.70 ; p<0.005)$.

Conclusion: The assays developed in this study mimic hospital environmental contamination events to demonstrate the performance of a MP to limit contamination under multiple conditions. Antimicrobial copper has been implemented in hospital room studies to evaluate its impact on nosocomial infections and a decrease in HAl rate was shown. Similar implementation of the MP has potential to reduce the incidence of HAls although future clinical studies will be necessary to validate the MP's true impact.

\section{Background}

Environmental surface contamination provides a potential reservoir for pathogens to persist and cause infection in susceptible patients [1,2]. Environmental surfaces near patients such as bed rails, tray tables, telephones, bedside tables, patient chairs, and nurse call buttons are often heavily contaminated [3-6]. Methicillin-resistant

\footnotetext{
* Correspondence: sreddy@sharklet.com

'Sharklet Technologies, Inc, 12635 E. Montview Blvd, Suite 160, Aurora, CO 80045, USA

Full list of author information is available at the end of the article
}

Staphylococcus aureus (MRSA) and Vancomycin-resistant Enterococcus (VRE) have been shown to survive on inanimate surfaces for a minimum of a few weeks and in some cases months [1,7-11]. Pathogens contaminate surfaces through large volume surface soaking (e.g. spills) or micro-droplet aspirations (e.g. sneezes) and are transferred subsequently to healthcare workers' hands and other objects (e.g. touch events) [12-14]. Recent evidence confirms that patients admitted to rooms previously occupied by patients infected or colonized with 
MRSA or VRE have an increased risk of acquiring the same pathogen as the prior room occupants [15-20].

Healthcare infection control guidelines from the Centers for Disease Control and Prevention (CDC) now emphasize the importance of cleaning and disinfecting "high-touch surfaces" and monitoring these activities to maintain a sanitary environment in the hospital [21]. These documents reflect an evolving mindset that patient area environmental cleanliness in healthcare settings plays a significant role in infection prevention and control. Despite the increased attention to environmental hygiene, recent studies have shown that as few as $40 \%$ of near patient surfaces are being cleaned in accordance with existing hospital policies $[6,10,16]$. Surprisingly few technological surface improvements have been implemented to address the problem of contaminated surfaces that exist between terminal cleanings [22]. Among the few, antimicrobial copper has recently been implemented as a technology to prevent surface contamination between cleanings. In one copper trial, patients who developed HAI and/or colonization of MRSA and VRE was significantly reduced from 0.123 to 0.071 ( $p=$ 0.02 ) for patients that resided in ICU rooms with copper as opposed to ICU rooms without copper [23]. The proportion of patients developing HAI alone was reduced from 0.081 to $0.034(p=0.013)$ where copper was used [23]. Unfortunately, copper and antimicrobial silver are expensive to implement and both utilize kill mechanisms which have potential to select for resistant organisms [24]. While the results of the copper trials may require further validation $[25,26]$, the data from these studies indicate that sustained surface contamination reduction may offer a clinical benefit.

A micropattern (MP) surface was evaluated to address the need for improved surface technology to resist bacterial contamination. Specifically, previous studies show the Sharklet MP to be the most effective among ordered topographies (pillars, channels, other geometries) for inhibiting bioadhesion (Figure 1) [27,28]. The MP reduces colonization of a variety of marine organisms and human pathogens in nutrient-rich environments [27,29-34]. The MP is a physical surface modification that does not introduce chemical additives or antimicrobials; therefore the bulk properties of the material are not affected by the presence of the textured surface. Alternative surface modifications reporting to limit bacterial contamination exist but were not tested here. They include examples like photo-activating agents, polyethylene glycol, and diamond-like carbon films and were reviewed recently for their roles in contamination mitigation [35].

Demonstration of MP efficacy requires testing designed to assess the remaining viable bacteria directly from the surface rather than enumerating bacteria remaining in solutions exposed to the surface as done

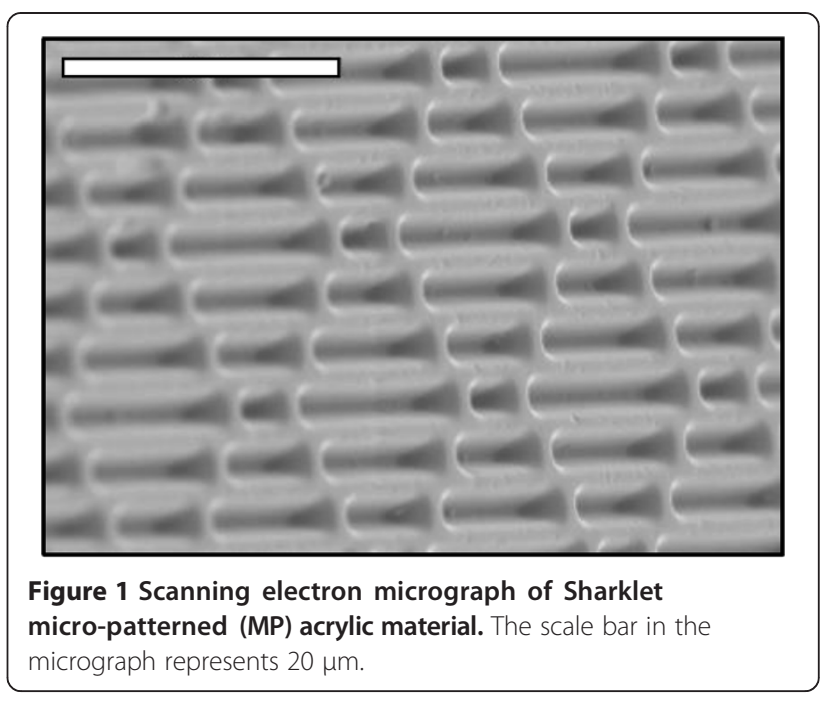

in existing standardized protocols for assessing antimicrobial surfaces [36]. Specific bacterial contamination scenarios were examined using immersion, spray, or touch transference inoculation methods with, MSSA and MRSA to mimic common contamination scenarios. Ultimately, through validation of individual inoculation methods, a combination of both bacterial transfer and persistence events were combined into a single assay. The combination method was used to compare the reduction of MSSA and MRSA on the MP to antimicrobial copper.

\section{Methods}

\section{Bacterial strains, growth conditions, and inoculums}

Bacterial strains used for testing included methicillinsensitive Staphylococcus aureus (MSSA; ATCC 6538) or methicillin-resistant S. aureus (MRSA; ATCC 43300), Each were grown in a shaking incubator at $37^{\circ} \mathrm{C}$ for $18-24 \mathrm{~h}$ in tryptic soy broth (TSB) media (Hardy Diagnostics, Santa Maria, CA). Prior to inoculation, strains were sub-cultured into fresh TSB at 1:100 dilution and grown for $4 \mathrm{~h}$. Inoculum suspensions were prepared by pelleting, resuspending and adjusting the cell concentration of the broth cultures in phosphate buffered saline (PBS; Hardy Diagnostics, Santa Maria, CA) using a known $\mathrm{OD}_{600} / \mathrm{CFU}$ ratio. Following the experiment, bacterial inoculation suspensions were evaluated for CFUs. Experiments with inoculums within $0.5 \log$ units of the target inoculum were accepted.

\section{Bacterial challenge on surfaces Test surface materials}

Flat polydimethylsiloxane elastomer (PDMSe; Dow Corning, Midland, MI) or acrylic film (Flexcon, Spenser, MA), was either cast against nickel shims or embossed with an inverse Sharklet ${ }^{\mathrm{TM}}$ micropattern (MP) or smooth 
surface (controls) by Sharklet Technologies, Inc (STI; Aurora, CO). The inverse MP consists of $2 \mu \mathrm{m}$ wide rectangular features with nonadjacent repeating lengths that are recessed into the surface and arranged in a periodic diamond pattern with $2 \mu \mathrm{m}$ spacing and a feature depth of $3 \mu \mathrm{m}$ (Figure 1). Copper foil, a 99.9\% pure alloy C11000 (Alaskan Copper and Brass Company, Seattle, WA), registered as a US EPA antimicrobial was purchased for antimicrobial copper testing. Each elastomer, plastic, or copper foil sample was firmly adhered to the bottom of a Petri dish, sterilized for $10 \mathrm{~m}$ with $95 \%$ ethanol, rinsed 3 times with deionized water and allowed to dry prior to each experiment. In each experimental method discussed, un-patterned smooth surfaces of the identical plastic material, or smooth acrylic for antimicrobial copper comparisons, were used as standards to achieve percent reduction calculations.

\section{Surface testing methods}

Experimental methods used to evaluate attachment and survival were based on a review of previous studies assessing surface contamination or antimicrobial efficacy on surfaces $[1,5,7,8,36-41]$. Three assays were developed that each evaluated varied aspects of real-world surface contamination scenarios.

\section{Spray inoculation assay}

To achieve even bacterial loading, the spray inoculation method was used to test MSSA. Suspensions ranging from $1 \times 10^{5}$ to $1 \times 10^{7} \mathrm{CFU} / \mathrm{ml}$ were prepared from logphase growth cultures in sterile $1 \times$ PBS. A Central Pneumatic Professional gravity-fed paint sprayer (Harbor Freight Tools, Camarillo, CA) was sterilized by spraying $50 \mathrm{ml}$ of $95 \%$ ethanol through the device and rinsed with $100 \mathrm{ml}$ of sterile deionized water. Using sterile $1 \times$ PBS, the appropriate spray conditions were optimized to deposit between 100-200 $\mu \mathrm{l}$ of fluid per dish. Per spray event, 5-6 plates were secured in the biological safety cabinet on test tube racks angled at approximately 45 degrees. The sprayer was connected to compressed nitrogen tank (General Air, Denver, CO) and was loaded with $50-100 \mathrm{ml}$ of prepared bacterial suspension. Test and control surfaces were cut into $40 \mathrm{~mm}$ radius semicircles and placed side-by-side in a single Petri dish. Experimental plates were weighed before and after spraying and the volume of delivered inoculum was calculated to ensure the samples were within the appropriate spray inoculum range for enumeration through RODAC sampling. RODAC sampling occurred directly following drying of $30 \mathrm{~m}$ at ambient conditions without rinsing. Additionally, a disruption and dilution sampling method, as described below as a previously optimized MSSA quantification standard protocol, was used as supplementary quantification methods to confirm the ability for the RODAC plates to recover cells from the surface after spray inoculation.

\section{Immersion inoculation assay}

Bacterial inoculums of MSSA or MRSA ranging from $1 \times 10^{3}$ to $1 \times 10^{4} \mathrm{CFU} / \mathrm{ml}$ completely submerged the test samples in the dish for $1 \mathrm{~h}$ at room temperature (RT). The bacterial suspension was then removed and the dishes were rinsed with sterile $1 \times$ PBS 3 times, for $10 \mathrm{~s}$ while rotating at $80 \mathrm{rpm}$, to remove non-attached cells. After discarding the final rinsate, surfaces were dried under ambient conditions for $1 \mathrm{~h}$ then sampled for viable bacteria using RODAC contact plates as described below.

\section{Touch transference inoculation assay}

MSSA and MRSA were used to evaluate the performance of the MP in this assay. Test and control surfaces were cut into $40 \mathrm{~mm}$ radius semi-circles and placed side-by-side in a single Petri dish. Bacterial suspensions $(5 \mathrm{ml})$ ranging from $1 \times 10^{5}$ to $1 \times 10^{7} \mathrm{CFU} / \mathrm{ml}$ were used to flood sterile velveteen cloths (Bel-Art Products, Wayne, NJ) that lined the bottom of sterile Petri dishes [42]. Sterile velveteen cloth was placed on a replica plating tool (Bel-Art Products, Wayne, NJ) and inverted onto saturated velveteen-containing bacterial inoculum for $10 \mathrm{~s}$ before being placed onto test and control surfaces for a $10 \mathrm{~s}$ contact time. The test surfaces were then allowed to dry for 5-10 s under ambient conditions before being sampled using RODAC contact plates, as described below.

\section{Combination transference and persistence assay}

Suspensions of MSSA and MRSA organisms ranging from $1 \times 10^{5}$ to $1 \times 10^{7} \mathrm{CFU} / \mathrm{ml}$ were each used to challenge smooth and the MP acrylic films. Test and control acrylic film was cut into $40 \mathrm{~mm}$ radius semi-circles and placed side-by-side in a single Petri dish. Touch transference inoculation (described above) was used to inoculate the challenge surfaces. Reduction of touch transference was measured after $0 \mathrm{~m}$ of drying and reduction of persistence was measured after $90 \mathrm{~m}$ of drying was added in combination while each time point was sampled using RODAC plates. Similarly, antimicrobial copper was subjected to challenge with MSSA and MRSA using the same combination transference and persistence testing in head-to-head comparison with the MP acrylic film.

\section{Sampling bacterial load RODAC contact agar}

Following inoculation and processing of each sample surface, bacterial load was quantified using RODAC contact agar plates. In each test, per organism investigated, 
the inoculation range was determined experimentally as being optimal for yielding a countable range of colonies on RODAC contact plates (BBL Prepared RODAC Plate, Trypticase Soy Agar with Lecithin and Polysorbate 80, BD, Franklin Lakes, NJ), which were used for cell recovery from sample surfaces. The agar contact method was used to directly quantify bacterial CFU transferred from the surface to a $60 \mathrm{~mm}$ diameter RODAC contact plate for enumeration of total colony counts. The RODAC contact plates were pressed onto inoculated surfaces for $5 \mathrm{~s}$ while avoiding air bubbles between the surface and RODAC plate. The RODAC plates were then incubated for $18-24 \mathrm{~h}$ at $37^{\circ} \mathrm{C}$. The RODAC plates were photographed and counted using magnification and Image $\mathrm{J}$ colony counting methods. The resulting colonies were enumerated, log transformed, and recorded as log CFU/ RODAC.

\section{Disruption and dilution plating}

Sterile biopsy punches ( $4 \mathrm{~mm}$; VWR International, Radnor, PA) were used to obtain samples from inoculated surfaces. Punches were dropped into conical tubes, each containing $1 \mathrm{ml}$ of fresh Dey-Engley (DE) neutralization buffer (Sigma, St. Louis, MO). The tubes were sonicated for two minutes with $30 \mathrm{~s}$ vortexes before and after sonication [41]. Serial dilution of the eluted bacteria in DE buffer was then plated onto TSA, and the plates were incubated for $18-24 \mathrm{~h}$ at $37^{\circ} \mathrm{C}$. Resulting colonies were enumerated, log transformed, and recorded as log CFU/ $\mathrm{ml}$.

\section{Microscopy analysis}

Scanning electron microscopy was used to visualize MSSA due to its ability to potentially exist within the patterned surface. After bacterial immersion, two samples of each the MP and two smooth samples were retained for analysis without RODAC exposure, while another two samples of each surface were stamped with a RODAC plate. Each sample was subsequently fixed with osmium tetroxide gas (Electron Microscopy Sciences, 19150) for $45 \mathrm{~m}$ and then subjected to a dehydration series with $10 \mathrm{~m}$ incubations in 25, 50, 75, and finally 95\% ethanol (Decon Labs Inc, King of Prussia, PA), then air-dried overnight at ambient conditions. Two $8 \mathrm{~mm}$ circles were taken near the center of each sample with a biopsy punch (Fisher, Waltham, MA), mounted, sputter-coated with gold, and analyzed via SEM. Two images were taken per smooth sample and four images were taken per the MP sample for qualitative image analysis.

\section{Data reporting and statistical analysis}

Each experiment consisted of at least three experimental replicates per surface type (the MP and smooth control), generating a log reduction value calculated from paired comparison of the MP and smooth surface mean log cell densities. Each single experiment was repeated at least three times to generate least squares mean log reduction (LR) values and establish statistical significance [43]. The resulting log reductions were subjected to a single t-Test and, when appropriate, an ANOVA analysis with a Tukey test to generate statistical significance and grouping across samples, materials, and strain types. Smooth control surface log cell densities were compared where appropriate to determine experimental variance for establishing optimum assay conditions.

\section{Results}

\section{Bacterial attachment to surfaces}

The immersion assay with RODAC recovery was used to quantify bacterial attachment to representative acrylic The MP and smooth surfaces after being inoculated with a bacterial suspension. MSSA and MRSA demonstrated significantly reduced attachment to the MP surfaces compared to smooth controls, with 99\% ( $\mathrm{LR}=2.18$; $p<0.001)$ and $98 \%(\mathrm{LR}=1.64 ; p<0.001)$ reductions of each of these organisms, respectively (Figure 2).

\section{Bacterial persistence on surfaces}

S. aureus (MSSA) was tested for persistence on the MP with RODAC recovery after a uniform spray inoculation technique, mimicking a common surface contamination event. MSSA was reduced by $98 \%(\mathrm{LR}=1.61 ; p<0.005)$ on the MP compared to smooth controls (Figure 3A). The MP reduction of MSSA contamination was also

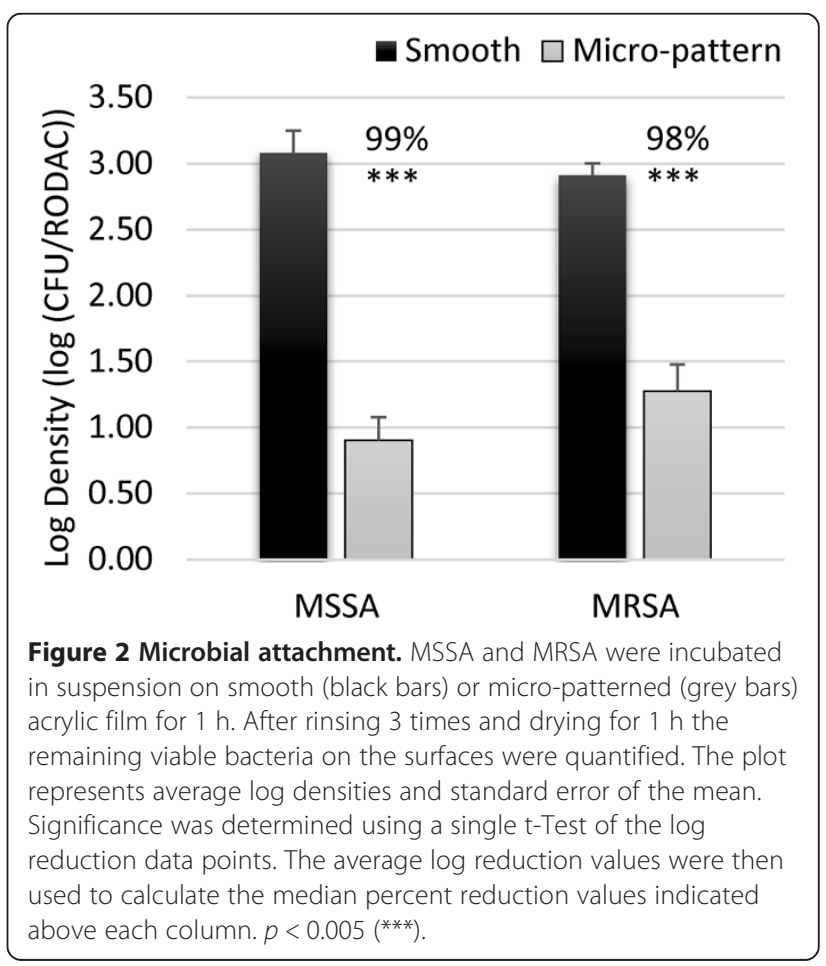




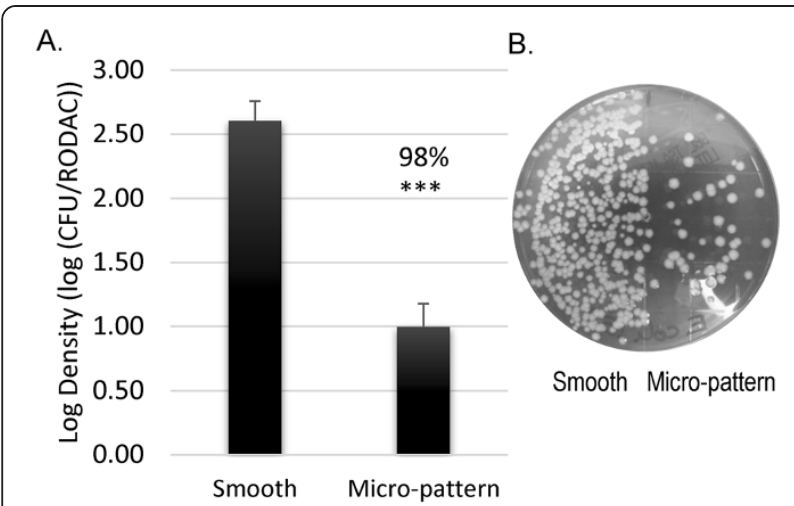

Figure 3 Microbial persistence. Smooth and micro-patterned (MP) acrylic films were challenged with a sprayed inoculum and dried for 30 m. A.) Log densities of bacteria present on the surfaces of the MP compared to smooth controls for MSSA are plotted with the associated standard error of the mean. B.) A representative image of a RODAC contact plate after MSSA sampling, the MP surface (right) has fewer bacteria compared to the smooth surface (left). $p<0.005$ $\left.{ }^{* * *}\right) n=3$.

visually apparent using RODAC recovery (Figure 3B). Sprayed surfaces were also sampled using disruption and dilution plating quantification. MSSA was significantly reduced on the MP compared to smooth surface (Additional file 1: Table S1) with this recovery method. Microscopy methods were utilized to ensure that the RODAC agar efficiently removed bacteria from the MP and smooth surfaces. Scanning electron microscopy (SEM) surface examination indicated that before RODAC recovery, the smooth silicone surface had extensive contamination compared to the MP surface (Additional file 2: Figure S1A and B). After RODAC recovery, both surfaces were without visible contamination (Additional file 2: Figure S1C and $\mathrm{D})$. These results are consistent with quantitative results from the immersion assay (Figure 2).

\section{Transfer and persistence of bacteria on surfaces}

Both MSSA and MRSA on a surfaces were evaluated using the combination transfer and persistence assay with RODAC recovery methods. Transfer of MSSA onto the MP acrylic film was reduced $87 \%(\mathrm{LR}=0.90 ; p<0.05)$ compared to smooth film (Figure 4). MSSA persistence on the MP was further reduced 97\% (LR $=1.54 ; p<0.001)$ after $90 \mathrm{~m}$ of drying (Figure 4). ANOVA analysis and Tukey grouping identified that reduction of MSSA after $0 \mathrm{~m}$ (transfer) grouped significantly differently $(p<0.05)$ than its reductions seen after $90 \mathrm{~m}$ of drying (survival). The MP reduced MRSA compared to smooth controls by 91\% $(\mathrm{LR}=1.04 ; p<0.005)$ after $0 \mathrm{~m}$ and $94 \%(\mathrm{LR}=1.26$; $p<0.005)$ after $90 \mathrm{~m}$ of drying (Figure 4).

Antimicrobial copper, which is marketed for its ability to reduce environmental contamination [23,44], was not effective at reducing MSSA contamination compared to smooth acrylic film after $0 \mathrm{~m}$ or $90 \mathrm{~m}$. Copper did reduce MRSA by $80 \%(\mathrm{LR}=0.70 ; p<0.002)$ after $0 \mathrm{~m}$ and $79 \%(\mathrm{LR}=0.69 ; n s)$ after $90 \mathrm{~m}$ of drying compared to smooth controls (Figure 4). Importantly, the MP reductions in MSSA contamination grouped in statistically higher log reduction groups from that of antimicrobial copper using Tukey post-test ANOVA analysis. These data demonstrated that the MP was more effective than antimicrobial copper surfaces in limiting bacterial contamination transfer and survival in the touch transfer assay.

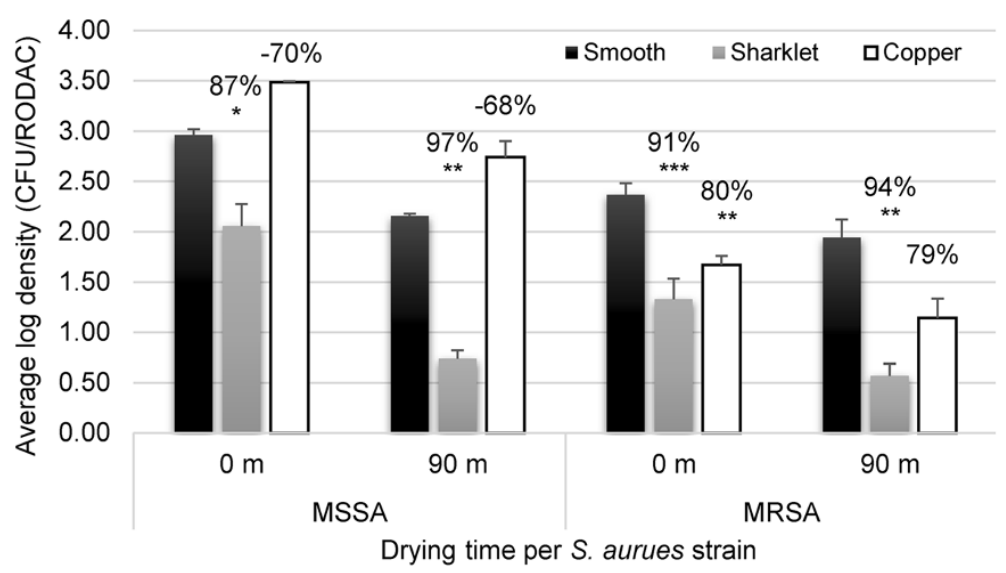

Figure 4 Comparison of Sharklet MP to Copper antimicrobial surface. MSSA and MRSA were used to challenge smooth unpatterned film, the MP film, and copper foil (99.9\% pure) using a touch incident with time points sampled after 0 and $90 \mathrm{~m}$ of drying. Average log density values are presented for smooth, the MP, and copper surfaces. Error bars represent the SEM for 3 independent experiments. The percent reduction values were calculated using individual log reduction values comparing either Sharklet MP or copper to smooth control samples. $p<0.05\left(^{*}\right)$, $p<0.01$ (**) $^{*}, p<0.005$ (***) $^{*}$. 


\section{Discussion}

The MP consistently demonstrated a reduction in microbial attachment, transference, and survival following simulated real-world inoculation methods. While the initial phase of this study identified the MP's ability to limit bacterial attachment of MSSA and MRSA (Figure 2), high-touch surfaces in the environment are commonly contaminated by touch and sneeze-like events and not complete immersion. Additionally, the MP has potential to limit transference and persistence of bacteria, but the immersion method did not allow evaluation of those individual events. Therefore methods were further developed to simulate real-world inoculation events. Spray inoculation allowed for uniform and reproducible loading of inoculum onto surfaces to evaluate bacterial persistence over time $(30-90 \mathrm{~m})$ and touch transference assays were used to mimic indirect bacterial spread on high-touch surfaces through transfer alone therefore those assays required sampling after $0 \mathrm{~m}$. Bacterial loads were sampled from the MP or smooth surfaces using RODAC contact plates $[5,45,46]$. The RODAC plates were used to quantify remaining bacterial loads, which proved to be a reproducible method which is not commonly used in standardized test methods $[36,47,48]$. Validation of RODAC sampling efficacy was done qualitatively using SEM (Additional file 2: Figure S1) and quantitatively using previously-optimized ultra-sonication (Additional file 1: Table S1) [34,41,49,50]. These data substantiate the use of RODAC contact sampling to test the bacterial load present after inoculation and drying on both the MP and smooth surfaces. Importantly, the MP demonstrated reduced bacterial contamination regardless of the inoculation and sampling method.

Interestingly, significantly superior reductions in bacterial load of MSSA on the MP after both transfer and survival time points compared to transfer alone were identified using Tukey grouping analysis (Figure 4; $p<0.05)$. This suggests that independent mechanisms are limiting bacterial transfer as well as bacterial survival after interaction with the MP surface. This report is the first to demonstrate that use of a microtopography can result in accelerated loss of bacterial viability compared to a smooth surface (Additional file 1: Table S1). Loss of bacterial viability following reduced bacterial surface interaction is not surprising since microbial transition to a tolerant sessile physiology relies heavily on surface adherence $[51,52]$. The MP was engineered and optimized to achieve specific surface energies, which reduce bacterial interaction and attachment compared to a smooth surface $[29,53]$. Therefore, the inability for bacteria to efficiently adhere to the MP is potentially responsible for the loss of bacterial viability in addition to the limited initial transfer of bacteria to the MP.
Antimicrobial copper has been the most popularly implemented surface technology able to demonstrate a reduction in bacterial contamination in both laboratory and clinical environmental testing $[23,44]$. Therefore, in this study, antimicrobial copper was compared to the $\mathrm{MP}$, and the MP outperformed antimicrobial copper in reduction of bacterial transfer and survival. Copper was ineffective in limiting MSSA, while the MP reduced MSSA by up to $97 \%(\mathrm{p}<0.05)$ when compared to smooth acrylic control surfaces. Copper demonstrated $80 \%(\mathrm{p}<0.002)$ reduction of MRSA as compared to $94 \%$ $(\mathrm{p}<0.005)$ reduction with the MP (Figure 4$)$. The finding that the MP was more effective at limiting bacterial load $90 \mathrm{~m}$ after inoculation is intriguing. While the MP surface limits initial transfer due to surface energy changes [53,54] as well as perceived persistence of organisms, the copper surfaces appear to only limit persistence based on cytotoxic effects occurring after longer durations. The fact that the MP does not require cytotoxic compounds or leaching chemicals to be an effective alternative to traditional antimicrobials such as copper for limiting bacterial contamination is a distinct advantage.

The impact of these results is highly relevant given the evidence linking surface contamination to nosocomial infections $[5,11,55,56]$. Survival of $S$. aureus (including MRSA) on dry inanimate surfaces can range from 7 days to 7 months [8]. The existing and emerging surface decontamination and cleaning methodologies were clearly evaluated in a recent review by Weber and Rutala [22]. They discussed advantages and disadvantages of many hygiene practices and contamination resistant surfaces including the MP. Unfortunately, they found that while education and improved hygiene practices would theoretically contribute to fewer HAIs, little positive effects have been observed. Therefore, a technology that limits contamination regardless of human error is warranted. Additionally, chemical antimicrobial applications can also be problematic to vulnerable patient populations including neonates and young children and are often avoided. Wide implementation of antimicrobial surface technologies with direct kill mechanisms are concerning due to their potential to provide selective pressure for resistant micro-organisms. Heavy metal resistance has already been identified with clinically-relevant bacterial species showing resistance to silver $[24,57,58]$ and copper [59]. The MSSA strain tested in this study exhibited tolerance to copper surfaces for $90 \mathrm{~m}$ but not to the MP. Considering that antimicrobial copper surfaces have been shown to reduce HAI rates combined with MRSA or VRE colonization when implemented in ICU rooms [23] and the MP outperformed copper when testing transfer and survival of MSSA and MRSA in vitro, this study suggests that the MP may help reduce infection 
rates and improve patient care. Continued testing of the MP surfaces in clinical settings should provide further evidence of the nature and magnitude of the benefits to patients.

\section{Conclusion}

The MP surface is an effective and attractive method to broadly reduce microbial contamination on surfaces without the use of antimicrobial agents. The studies presented here clearly demonstrate that the MP reduces microbial transfer and when compared to the same material without the MP present. When adopted into real-world use, application of the MP onto high-touch surfaces in hospitals or shared public spaces is expected to limit environmental contamination of infectious microorganisms. Given that preliminary clinical evidence exists that antimicrobial copper implementation in hospital rooms decreases HAI rate, similar implementation of the MP, which outperformed copper in the transfer and persistence in vitro study, has potential to reduce the incidence of HAIs.

\section{Additional files}

Additional file 1: Table S1. Quantification of bacterial persistence using dilution plating. MSSA was aerosolized onto smooth or the MP acrylic film and allowed to dry for $90 \mathrm{~m} .8 \mathrm{~mm}$ biopsy punches were used to cut film samples to suspend bacteria and dilution plate. Smooth and MP associated log densities with resulting log reductions are presented along with the $p$ value using a single paired t-Test.

Additional file 2: Figure S1. MSSA contamination persistence recovery. $1 \times 10^{7} \mathrm{CFU} / \mathrm{mL}$ was prepared to immerse smooth and the MP surfaces. Samples immersed in a suspension of MSSA were rinse 3 times, sampled, and then prepared for SEM imaging. Smooth surface before RODAC (A) and Sharklet MP before RODAC sampling (B) are pictured adjacent to images after RODAC sampling (C and D)

\section{Competing interests}

All authors, except ABB, completed work while being employed by Sharklet Technologies, Inc. ABB is a paid consultant of Sharklet Technologies, Inc.

\section{Authors' contributions}

All authors had significant contributions to the science discussed. EEM, DM, RM Mettetal, RM May, EMD, KKC, ABB, and STR all contributed to the design and objectives of experimental analysis. EEM, DM, MR Mettetal, and RM May combined to carry out testing. All authors read and approved the final manuscript.

\section{Acknowledgements}

The authors would like to recognize the support of Melinda Sogo, Trevor Hostetter, Michael Drinker, Bristi Basu, and Caroline Flores for their support in completing experiment tasks and laboratory support. Additionally, test material development and innovation support provided by Mark Spiecker, MiKayla Henry, Kelley Doebler, and Bryce Stevenson. Test material also provided by Ryan Stoneberg and Gurpreet Chhiber at 10x Microstructures and Bill Sullivan and Dave Constantine at FLEXcon.

\section{Author details}

${ }^{1}$ Sharklet Technologies, Inc, 12635 E. Montview Blvd, Suite 160, Aurora, CO 80045, USA. ²Department of Materials Science and Engineering, University of Florida, Gainesville, FL, USA.

Received: 28 April 2014 Accepted: 20 August 2014

Published: 17 September 2014

\section{References}

1. Boyce JM: Environmental contamination makes an important contribution to hospital infection. J Hosp Infect 2007, 65(Suppl 2):50-54.

2. Boyce JM, Potter-Bynoe G, Chenevert C, King T: Environmental contamination due to methicillin-resistant Staphylococcus aureus: possible infection control implications. Infect Control Hosp Epidemiol 1997, 18:622-627.

3. Boyce JM, Havill NL, Otter JA, Adams NM: Widespread environmental contamination associated with patients with diarrhea and methicillin-resistant Staphylococcus aureus colonization of the gastrointestinal tract. Infect Control Hosp Epidemiol 2007, 28:1142-1147.

4. Carling PC, Briggs J, Hylander D, Perkins J: An evaluation of patient area cleaning in 3 hospitals using a novel targeting methodology. Am J Infect Control 2006, 34:513-519.

5. Carling PC, Bartley JM: Evaluating hygienic cleaning in health care settings: what you do not know can harm your patients. Am J Infect Control 2010, 38:S41-S50.

6. White LF, Dancer SJ, Robertson C, McDonald J: Are hygiene standards useful in assessing infection risk? Am J Infect Control 2008, 36:381-384.

7. Huang R, Mehta S, Weed D, Price CS: Methicillin-resistant Staphylococcus aureus survival on hospital fomites. Infect Control Hosp Epidemiol 2006, 27:1267-1269.

8. Kramer A, Schwebke I, Kampf G: How long do nosocomial pathogens persist on inanimate surfaces? A systematic review. BMC Infect Dis 2006, 6:130.

9. Dancer SJ: The role of environmental cleaning in the control of hospital-acquired infection. J Hosp Infect 2009, 73:378-385.

10. Carling PC, Parry MM, Rupp ME, Po JL, Dick B, Von Beheren S, Healthcare Environmental Hygiene Study Group: Improving cleaning of the environment surrounding patients in 36 acute care hospitals. Infect Control Hosp Epidemiol 2008, 29:1035-1041.

11. Weber DJ, Rutala WA, Miller MB, Huslage K, Sickbert-Bennett E: Role of hospital surfaces in the transmission of emerging health care-associated pathogens: norovirus, Clostridium difficile, and Acinetobacter species. Am J Infect Control 2010, 38:S25-S33.

12. Bhalla A, Pultz NJ, Gries DM, Ray AJ, Eckstein EC, Aron DC, Donskey CJ: Acquisition of nosocomial pathogens on hands after contact with environmental surfaces near hospitalized patients. Infect Control Hosp Epidemiol 2004, 25:164-167.

13. Hayden MK, Blom DW, Lyle EA, Moore CG, Weinstein RA: Risk of hand or glove contamination after contact with patients colonized with vancomycin-resistant enterococcus or the colonized patients' environment. Infect Control Hosp Epidemiol 2008, 29:149-154.

14. Morgan DJ, Liang SY, Smith CL, Johnson JK, Harris AD, Furuno JP, Thom KA, Snyder GM, Day HR, Perencevich EN: Frequent multidrug-resistant Acinetobacter baumannii contamination of gloves, gowns, and hands of healthcare workers. Infect Control Hosp Epidemiol 2010, 31:716-721.

15. Denton M, Wilcox MH, Parnell P, Green D, Keer V, Hawkey PM, Evans I, Murphy P: Role of environmental cleaning in controlling an outbreak of Acinetobacter baumannii on a neurosurgical intensive care unit. Intensive Crit Care Nurs 2005, 21:94-98.

16. Hayden MK, Bonten MJ, Blom DW, Lyle EA, van de Vijver DA, Weinstein RA Reduction in acquisition of vancomycin-resistant enterococcus after enforcement of routine environmental cleaning measures. Clin Infect Dis 2006, 42:1552-1560.

17. Huang SS, Datta R, Platt R: Risk of acquiring antibiotic-resistant bacteria from prior room occupants. Arch Intern Med 2006, 166:1945-1951.

18. Hardy K, Oppenheim BA, Gossain S, Gao F, Hawkey PM: A study of the relationship between environmental contamination with methicillin-resistant Staphylococcus aureus (MRSA) and patients' acquisition of MRSA. Infect Control Hosp Epidemiol 2006, 27:127-132.

19. Datta R, Platt R, Yokoe DS, Huang SS: Environmental cleaning intervention and risk of acquiring multidrug-resistant organisms from prior room occupants. Arch Intern Med 2011, 171:491-494.

20. Drees M, Snydman DR, Schmid CH, Barefoot L, Hansjosten K, Vue PM, Cronin M, Nasraway SA, Golan Y: Antibiotic exposure and room contamination among patients colonized with vancomycin-resistant enterococci. Infect Control Hosp Epidemiol 2008, 29:709-715.

21. Siegel JD, Rhinehart E, Jackson M, Chiarello L, Health Care Infection Control Practices Advisory C: Guideline for Isolation Precautions: Preventing Transmission of Infectious Agents in Health Care Settings. Am J Infect Control 2007, 2007(35):S65-S164. 
22. Weber DJ, Rutala WA: Self-disinfecting surfaces: review of current methodologies and future prospects. Am J Infect Control 2013, 41:S31-S35.

23. Salgado CD, Sepkowitz KA, John JF, Cantey JR, Attaway HH, Freeman KD, Sharpe PA, Michels HT, Schmidt MG: Copper surfaces reduce the rate of healthcare-acquired infections in the intensive care unit. Infect Control Hosp Epidemiol 2013, 34:479-486.

24. Silver S: Bacterial silver resistance: molecular biology and uses and misuses of silver compounds. FEMS Microbiol Rev 2003, 27:341-353.

25. Weber DJ, Rutala WA: Understanding and preventing transmission of healthcare-associated pathogens due to the contaminated hospital environment. Infect Control Hosp Epidemiol 2013, 34:449-452.

26. Harbarth S, Maiwald M, Dancer SJ: The environment and healthcare-acquired infections: why accurate reporting and evaluation of biological plausibility are important. Infect Control Hosp Epidemiol 2013, 34:996-997.

27. Schumacher JF, Carman ML, Estes TG, Feinberg AW, Wilson LH, Callow ME, Callow JA, Finlay JA, Brennan AB: Engineered antifouling microtopographies - effect of feature size, geometry, and roughness on settlement of zoospores of the green alga Ulva. Biofouling 2007, 23:55-62.

28. Schumacher JF, Long CJ, Callow ME, Finlay JA, Callow JA, Brennan AB: Engineered nanoforce gradients for inhibition of settlement (attachment) of swimming algal spores. Langmuir 2008, 24:4931-4937.

29. Carman ML, Estes TG, Feinberg AW, Schumacher JF, Wilkerson W, Wilson LH, Callow ME, Callow JA, Brennan AB: Engineered antifouling microtopographies-correlating wettability with cell attachment. Biofouling 2006, 22:11-21.

30. Chung KK, Schumacher JF, Sampson EM, Burne RA, Antonelli PJ, Brennan $A B$ : Impact of engineered surface microtopography on biofilm formation of Staphylococcus aureus. Biointerphases 2007, 2:89-94.

31. Schumacher JF, Aldred N, Callow ME, Finlay JA, Callow JA, Clare AS, Brennan $A B$ : Species-specific engineered antifouling topographies: correlations between the settlement of algal zoospores and barnacle cyprids. Biofouling 2007, 23:307-317.

32. Long CJ, Schumacher JF, Robinson PA 2nd, Finlay JA, Callow ME, Callow JA, Brennan $A B$ : A model that predicts the attachment behavior of Ulva linza zoospores on surface topography. Biofouling 2010, 26:411-419.

33. Magin CM, Long CJ, Cooper SP, Ista LK, Lopez GP, Brennan AB: Engineered antifouling microtopographies: the role of Reynolds number in a model that predicts attachment of zoospores of Ulva and cells of Cobetia marina. Biofouling 2010, 26:719-727.

34. Reddy ST, Chung KK, McDaniel CJ, Darouiche RO, Landman J, Brennan AB: Micropatterned surfaces for reducing the risk of catheter-associated urinary tract infection: an in vitro study on the effect of sharklet micropatterned surfaces to inhibit bacterial colonization and migration of uropathogenic Escherichia coli. J Endourol 2011, 25:1547-1552.

35. Humphreys H: Self-disinfecting and Microbiocide-Impregnated Surfaces and Fabrics: What Potential in Interrupting the Spread of Healthcare-Associated Infection? Clin Infect Dis 2014, 58:848-853.

36. D6329 A: Standard Guide for Developing Methodology for Evaluating the Ability of Indoor Materials to Support Microbial Growth Using Static Environmental Chambers. In Book Standard Guide for Developing Methodology for Evaluating the Ability of Indoor Materials to Support Microbial Growth Using Static Environmental Chambers. West Conshohocken, PA: ASTM International; 2003.

37. Neely AN, Maley MP: Survival of enterococci and staphylococci on hospital fabrics and plastic. J Clin Microbiol 2000, 38:724-726.

38. Lemmen SW, Hafner H, Zolldann D, Amedick G, Lutticken R: Comparison of two sampling methods for the detection of gram-positive and gram-negative bacteria in the environment: moistened swabs versus Rodac plates. Int J Hyg Environ Health 2001, 203:245-248.

39. Rutala WA, White MS, Gergen MF, Weber DJ: Bacterial contamination of keyboards: efficacy and functional impact of disinfectants. Infect Control Hosp Epidemiol 2006, 27:372-377.

40. Brooke JS, Annand JW, Hammer A, Dembkowski K, Shulman ST: Investigation of bacterial pathogens on 70 frequently used environmental surfaces in a large urban U.S. university. J Environ Health 2009, 71:17-22.

41. Kobayashi H, Oethinger M, Tuohy MJ, Procop GW, Bauer TW: Improved detection of biofilm-formative bacteria by vortexing and sonication: a pilot study. Clin Orthop Relat Res 2009, 467:1360-1364.

42. Lederberg J, Lederberg EM: Replica plating and indirect selection of bacterial mutants. J Bacteriol 1952, 63:399-406.
43. Hamilton MA, Hamilton GC, Goeres DM, Parker AE: Guidelines for the statistical analysis of a collaborative study of a laboratory method for testing disinfectant product performance. J AOAC Int 2013, 96:1138-1151.

44. Schmidt MG, Attaway HH, Sharpe PA, John J Jr, Sepkowitz KA, Morgan A, Fairey SE, Singh S, Steed LL, Cantey JR, Freeman KD, Michels HT, Salgado CD: Sustained reduction of microbial burden on common hospital surfaces through introduction of copper. J Clin Microbio/ 2012, 50:2217-2223.

45. Pinto F, Hiom S, Girdlestone S, Maillard JY: Evaluation of the effectiveness of commercially available contact plates for monitoring microbial environments. Lett Appl Microbiol 2009, 48:379-382.

46. Page K, Wilson M, Parkin IP: Antimicrobial surfaces and their potential in reducing the role of the inanimate environment in the incidence of hospital-acquired infections. J Mater Chem 2009, 19:3819-3831.

47. 22196:2007(E) IIS: Plastics-Measurement of Antimicrobial Activity on Plastic Surfaces. In Book Plastics-Measurement of Antimicrobial Activity on Plastic Surfaces. Geneva, Switzerland: ISO International; 2007.

48. E2149-01 AS: Standard Test Method for Determining the Antimicrobial Activity of Immobilized Antimicrobial Agents Under Dynamic Contact Conditions. In Book Standard Test Method for Determining the Antimicrobial Activity of Immobilized Antimicrobial Agents Under Dynamic Contact Conditions. West Conshohocken, PA: ASTM International; 2001.

49. Bjerkan G, Witso E, Bergh K: Sonication is superior to scraping for retrieval of bacteria in biofilm on titanium and steel surfaces in vitro. Acta Orthop 2009, 80:245-250

50. van de Belt H, Neut D, Schenk W, van Horn JR, van Der Mei HC, Busscher HJ: Staphylococcus aureus biofilm formation on different gentamicin-loaded polymethylmethacrylate bone cements. Biomaterials 2001, 22:1607-1611.

51. Potts M, Slaughter SM, Hunneke FU, Garst JF, Helm RF: Desiccation tolerance of prokaryotes: application of principles to human cells. Integr Comp Biol 2005, 45:800-809.

52. Kuchma SL, O'Toole GA: Surface-induced and biofilm-induced changes in gene expression. Curr Opin Biotechnol 2000, 11:429-433.

53. Decker JT, Kirschner CM, Long CJ, Finlay JA, Callow ME, Callow JA, Brennan AB: Engineered antifouling microtopographies: an energetic model that predicts cell attachment. Langmuir 2013, 29:13023-13030.

54. Long CJ, Finlay JA, Callow ME, Callow JA, Brennan AB: Engineered antifouling microtopographies: mapping preferential and inhibitory microenvironments for zoospore attachment. Biofouling 2010, 26:941-952.

55. Hota B: Contamination, disinfection, and cross-colonization: are hospital surfaces reservoirs for nosocomial infection? Clin Infect Dis 2004 39:1182-1189.

56. Sattar SA: Promises and pitfalls of recent advances in chemical means of preventing the spread of nosocomial infections by environmental surfaces. Am J Infect Control 2010, 38:S34-S40.

57. Percival SL, Bowler PG, Russell D: Bacterial resistance to silver in wound care. J Hosp Infect 2005, 60:1-7.

58. Silvestry-Rodriguez N, Sicairos-Ruelas EE, Gerba CP, Bright KR: Silver as a disinfectant. Rev Environ Contam Toxicol 2007, 191:23-45.

59. Santo CE, Morais PV, Grass G: Isolation and characterization of bacteria resistant to metallic copper surfaces. App/ Environ Microbiol 2010, 76:1341-1348

doi:10.1186/2047-2994-3-28

Cite this article as: Mann et al:: Surface micropattern limits bacterial contamination. Antimicrobial Resistance and Infection Control 2014 3:28 